\title{
WORLD EXPERIENCE IN THE INTRODUCTION OF MODERN INNOVATION AND INFORMATION TECHNOLOGIES IN THE FUNCTIONING OF FINANCIAL INSTITUTIONS
}

\author{
Olha Popelo', Maksym Dubyna², Nataliia Kholiavko³
}

\begin{abstract}
The article reveals the essence of the concept of "financial innovations" and their features. The classification of financial innovations is given. The innovative models of the Ukrainian banking business development are analysed. The innovative developments of the world's leading banks are systematized according to the version of the annual competition for the BAI-Finance Global Banking Innovation Awards held in Las Vegas. The innovative and information technologies in the work of financial institutions in the following areas are analysed: Product and Service Financial Innovation, Channel Financial Innovation, Financial Innovation in Social and Community Impact, Financial Innovation in Internal Process Improvement. Foreign experience and features of the development of the newest innovative information technologies in the financial services market are analysed. The subject of research is theoretical and applied aspects of the development of innovations and information technologies in the functioning of world-class financial institutions. The purpose of the article is to analyse and systematize foreign experience in the development of new innovative and information technologies in the financial services market. In the research, the authors used general scientific and specific methods, including: historical-logical, dialectical, deductive, analysis and synthesis, grouping, abstraction and formalization, benchmarking, generalizations and systematization. The article concludes that in modern rapidly evolving digitalization processes, financial innovations play an extremely important role and contribute to the economic development of countries. The authors point out that banking institutions need to focus their potential as much as possible on identifying priority digital and innovative initiatives, taking into account current challenges and threats. Finally, the effective use of specific financial innovations requires in-depth knowledge of the features of their operation and careful analysis of their consequences. The authors recommend the use of a cross-functional approach, which provides flexibility and the ability to transform change over time and is an important element in the process of implementing financial innovations. Taking into account the experience of leading banking institutions that actively implement innovative developments, the authors note that along with the benefits, financial innovations can cause new challenges and threats for all participants in this process. Researchers have shown that radical innovation can displace a dominant business model or technology and create a new market. According to the results of the analysis of innovative developments of banks around the world for the period 2015-2019, the authors found that financial innovations have changed their nature and are based on the latest digital technologies.
\end{abstract}

Key words: financial institutions, financial market, financial innovations, in-novation, information technologies, Fintech, digital technologies, bank, credit institu-tions, business models.

JEL Classification: O31, G21

\footnotetext{
Corresponding author:

${ }^{1}$ Chernihiv Polytechnic National University, Ukraine.

E-mail: popelo.olha@gmail.com

ORCID: https://orcid.org/0000-0002-4581-5129

ResearcherID: I-8572-2016

${ }^{2}$ Chernihiv Polytechnic National University, Ukraine.

E-mail: maksim-32@ukr.net

ORCID: https://orcid.org/0000-0002-5305-7815

ResearcherID: F-3291-2014

${ }^{3}$ Chernihiv Polytechnic National University, Ukraine.

E-mail: nateco@meta.ua

ORCID: https://orcid.org/0000-0003-2951-7233

ResearcherID: N-1229-2019
} 


\section{Introduction}

In today's rapidly evolving digitalization processes, traditional approaches to the provision of banking services and banking business no longer meet the growing demand and expectations of customers, do not meet the requirements of the efficiency and profitability. In the context of digitalization and active implementation of financial innovations, it is necessary to constantly look for advanced solutions and work on developing new business models that will best meet the changing needs of customers.

Growing competition both from financial institutions, high-tech companies and "Fintech" startups, which with their innovative solutions seek to become the leaders in highly profitable segments of the banking sector, requires the formation of an innovative strategy to respond to the new trends in the economy digitalization.

Considering approaches to the classification of financial innovations, scientists distinguish innovations by sources of origin, motives, types, effect of application, factors influencing the process of creation and implementation, the moment of creation, elements of the financial system where innovations take place.

However, regardless of the type of innovation, the question arises: when does a banking product or service acquire signs of innovation and cease to be an innovation? As soon as a banking product becomes mass, it is used by almost all banks and is available to most of its consumers, it ceases to be new and becomes traditional. The banking operation, in contrast to the banking innovation, has a significantly longer service life. It is the mass use of a new product that makes it non-innovative. The banking innovation has time constraints. It operates only within a certain period, which is determined by the starting and ending points of the life cycle of the innovation, but not the banking product. This means that banking innovations cannot be generally accepted transactions that are widely used. The banking innovation cannot be considered a banking product or operation that is new only to this bank, but which has long been implemented in other banks either (Loiko V., Bashkyrtseva T., 2018).

Innovative development is a hallmark of successful economies in many highly developed countries. The ever-growing connection between science and business, the widespread introduction of innovative information technologies in all spheres of activity, the constant renewal or improvement of products and services, the introduction of modern forms and methods of management can increase competitiveness and are an integral part of the innovative economic development.

Despite a significant amount of works of domestic and foreign scientists in the direction of studying the peculiarities of the financial institutions functioning, the existing scientific works are incompletely analysed, and foreign experience in the development of new innovative information technologies in the financial services market is analysed.

The purpose of the article is to analyse and systematize foreign experience in the development of new innovative and information technologies in the financial services market.

\section{Literature review}

Many Many scientists devote their papers to the study of modern innovative and information technologies, including their introduction into the work of financial institutions, namely Al-Kaber M. (2010), Anderloni L., Bongini, P. (2009), Błach Joanna (2011), Butko M. (2019), Chien-Chiang Lee, Chih-Wei Wang (2020), Chrystalla Kapetaniou (2018), Daniel Ruiz-Palomo (2021), Domingo García-Pérez-de-Lema (2021), Ebubekir Mollaahmetoğlu (2019), Ekkert M. (2019), Ellis L. C. Osabutey (2020), Fabozzi F. J. (2003), Fedyshyn M. F. (2019), Frame W. S. (2009), Hui An, Ruibo Yang (2021), Ivanova N. (2020), Katrin Hahn (2019), Kostohryz V. G. (2021), Leonardo Fernando Cruz Basso (2018), Loiko V. (2018), Maliarova V. O. (2021), Shkarlet S. (2019), Vovk V. Y. (2019), YangYang Chen (2021), Zhezherun Yu. V. (2021) and others.

Using the example of the established German industrial companies, Katrin Hahn from the Netherlands examine the extent to which financialization and financial market actors steer innovation strategies and practices. In-depth interviews with companies, cluster managers and banks and reviews of financing data do not reveal a direct influence of financial investors on innovation activities. On the contrary, companies' managements still have the power to decide how much financial control and standardization they allow for their companies' innovation practices. The pressure on these German companies to innovate comes from their strong market orientation rather than from financialization (Katrin Hahn, 2019).

The research by the Chinese scientists evaluates the impact of financial innovation on the banks growth and how their growth is affected by various dimensions of institutional environments' interaction with financial innovation. To address these relationships, they use different measures of financial innovation and bank growth from a panel dataset of 40 countries (Chien-Chiang Lee; ChihWei Wang; Shan-Ju Ho, 2020).

The paper by Chrystalla Kapetaniou, Marios Samdanis, Soo HeeLee (Cyprus, the UK) extends the literature on National Innovation Systems, arguing that innovation policies should incorporate the particular needs of a nation's innovation system and the current conditions of that nation's financial environment. This development is important because the financial 
environment is malleable and subject to exogenous events, such as recent global financial crisis. The relationship between a National Innovation System and the financial environment is presented through an analytical framework, which can be used to assess and instigate national innovation policies (Chrystalla Kapetaniou; Marios Samdanis; Soo Hee Lee, 2018).

The study of the Chinese and Australian scientists proves that financial regulation and financial innovation tend to show a dynamic game process of 'regulationinnovation-re-regulation-re-innovation'. This paper constructs an evolutionary game model to simulate the above phenomena for analysing the stable equilibrium strategies between financial institutions and regulation institutions (Hui An; Ruibo Yang; Xuejiao Ma; Siqi Zhang; Sardar M. N. Islam, 2021).

Drawing on human capital and upper echelons theories, the study of the Spanish scientists analyses how the CEO's financial literacy influences a firm's technological innovation and investigates the mediating role of alleviating financial constraints of Small and Medium-sized Enterprises (SMEs) in the former relationship (Domingo García-Pérez-de-Lema; Daniel Ruiz-Palomo; Julio Diéguez-Soto, 2021).

Authors of the paper PK Senyo, Ellis L.C. Osabutey (UK) argue that understanding antecedents to the actual use of fintech innovations will lead to deepening financial inclusion. Using mobile money, a type of fintech innovation, this study adopts the Unified Theory of Acceptance and Use of Technology 2 (UTAUT2) and the Prospect theory. The findings show that performance and effort expectancy have significant relationship with the intention to use mobile money services (PK Senyo; Ellis L.C. Osabutey, 2020).

The paper by the Turkish scientists investigates the relationship between financial development, financial innovation, and economic growth using a panel data analysis. The sample covers fifteen countries. Financial development has been considered as a composite variable consisting of four components: financial access, financial depth, financial efficiency, and financial stability. The distinguishing feature of the paper is that it includes financial innovation as another component of financial development in addition to the cited four. The paper concludes that both financial development and financial innovation have significant impact on economic growth (Ebubekir Mollaahmetoğlu; Burçay Yaşar Akçalı, 2019).

Gang-Jin Wang, Yang-Yang Chen, Hui-Bin Si, Chi Xie, Julien Chevallier (China, France) propose the multilayer information spillover networks, including a return spillover layer, a volatility spillover layer, and an extreme risk spillover layer in the variance decomposition framework for comprehensively investigating the information spillovers and connectedness among 30 Chinese financial institutions (i.e., banks, securities, and insurers). They analyse the topological characteristics of static and dynamic multilayer networks at the system and institution levels (Gang-Jin Wang, Yang-Yang Chen, Hui-Bin Si, Chi Xie, Julien Chevallier, 2021).

The Brazilian scientists analyse the relationships among innovation efforts, the impacts of these innovations, and the financial performance of Brazilian companies. They hypothesize that innovation efforts do not directly transform into financial performance. Due to the inherent uncertainty of innovative projects, such efforts must first lead to effective innovation results or impacts before they are capable of contributing to a company's financial performance (Juliana Albuquerquer Saliba de Oliveira; Leonardo Fernando Cruz Basso; Herbert Kimura; Vinicius Amorim Sobreiro, 2018).

\section{Definitions and features of financial innovations}

Financial innovations are not a new phenomenon, as they have been accompanying the technological innovations from the very beginning. It is commonly known that financial and technical innovations are bound together and they evolve together over a time. On the one hand, the financial innovations provide a mechanism to finance innovative technological projects when traditional sources of funds are unavailable due to the high investment risk. On the other hand, the technological and economic progress resulting in the higher complexity of business processes and new types of risk forces the financial system and financial markets to adapt to the changes, to be modernized according to the new requirements of the business entities and to the challenges of the modern world. This leads to the conclusion that without financial innovations, the technological and economic development would slow down and the wealth of nations would be lower. At the same time, the application of the financial innovations would be limited without the demand arising from the technical progress (Błach, Joanna, 2011).

As there are no unified definitions of the financial innovations, like in the case of the technological ones, the systematization of this term is required. In most of the applied definitions, the financial innovations are presented in the narrow meaning, as mainly the product innovations are described (some of the most popular definition of financial innovations are presented in: Al-Kaber, 2010, p. 135-136; Anderloni and Bongini, 2009, p. 41-43; Fabozzi and Modigliani, 2003, p. 27-28; Frame and White, 2009, p. 3). By the analysis of these definitions, the main features of the product of financial innovations can be listed as follows:

1) they can be entirely new solutions or just traditional instruments in which new elements of construction have been introduced improving their liquidity and 
increasing the number of their potential applications as they are better suited to the circumstances of the time;

2) they can be used as substitutes to the traditional financial instruments improving the financial situation of the business entities using them;

3) they cannot be easily assigned to one particular segment of the financial market;

4) they can be used to hedge against the intensive volatility of the market parameters;

5) they can be used in a form of complex instruments including several simple, traditional financial instruments;

6) they can be used in a form of new financial processes or techniques or new strategies that primary use these new products.

Thus, to summarize the conclusion - the term "financial innovations" can be applied in two meanings: 1) according to the narrow approach, the financial innovations are defined as any new developments in financial instruments (entirely new instruments, combination of traditional instruments, modification of traditional instruments, new application of existing instruments, etc.),

2) according to the broad approach, the financial innovations include any new developments in any elements of the financial system (markets, institutions, instruments and regulations) (Błach, Joanna, 2011).

The interpretation of the essence of financial innovations is presented in Figure 1.

There are many approaches to the classification of financial innovations. Among the most common classification criteria are the following: sources of innovations, motives of using the financial innovations, types of innovations, the effect of the financial innovation application, factors influencing the process of creation and implementation of innovations, the moment of creation, elements of the financial system where the innovations occur (Figure 1).

Both banks and seven professional world banking laboratories are engaged in the development of banking innovations (Loiko, Bashkyrtseva, 2018):

1. Standard Bank (South Africa) - PlayRoom Innovation Center (operating since January 2015) is developing modern banking technologies.

2. Laboratories of the Capital One Bank (USA) consist of three laboratories located in Washington, New York and San Francisco. The main activity of these laboratories is aimed at developing pilot banking products and accelerating all digital activities of the bank.

3. Commonwealth Bank's Innovation Laboratory (Australia) develops new products, services and solutions together with customers, partners, startups and industry experts.

4. Citi's Innovation Lab (USA) has established a global network of innovation centers located in cities such as Tel Aviv, Dublin, Singapore, San Francisco and New York, which provide opportunities for innovation training for all employees at all levels.

5. Visa Innovation Center (USA) develops innovations in the field of banking software.

6. Chase Bank Development and Innovation Center (USA) specializes in the development of ATM technology, as well as new ways of interacting with customers.

7. BBVA Innovation Center (Spain) develops and implements a number of technological solutions.

Banking innovations may not include minor changes that do not change the content and nature of the banking product or operation, such as changes in interest rates on loans and deposits, the term of the deposit and loan agreement, etc. (Loiko, Bashkyrtseva, 2018).

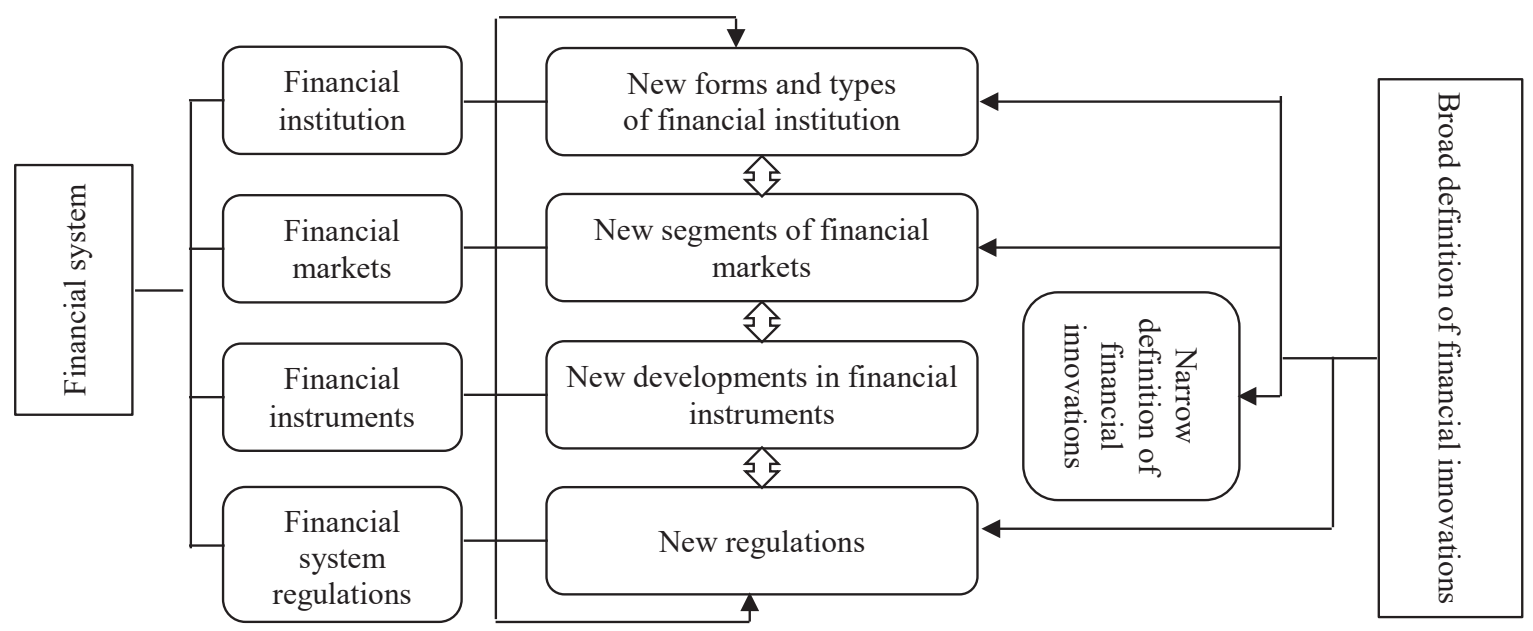

Figure 1. Interpretation of the essence of financial innovations

Source: developed by the authors 


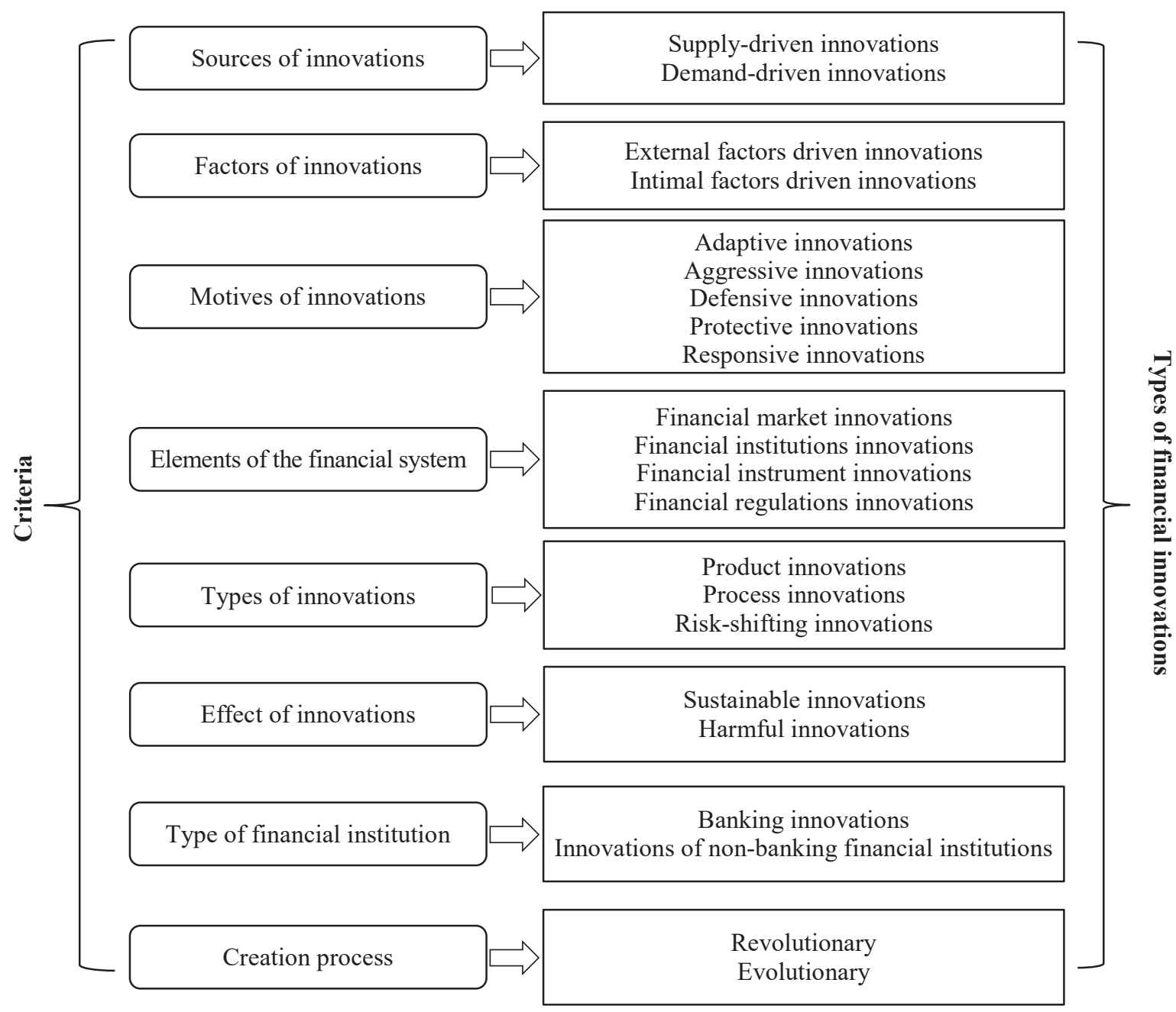

Figure 2. Classification of the financial innovations

Source: developed by the authors

\section{Innovative models of the Ukrainian banking business development}

For example, Ukrainian banks offer to use smartphones not only to pay for goods and services, but also to accept payments. Mobile application for business is offered by two Ukrainian banks - Raiffeisen Bank Aval (Pay-Me Ukraine) and Privatbank (iPay). Both banks produce card readers that connect to the smartphone via a headphone jack. Completed with a special application, the devices allow couriers, taxi drivers and small outlets to accept plastic cards for payment. Thanks to the mini-terminals of Privatbank together with the startup Poster it was possible to create a full-fledged cash register on a smartphone or a tablet. All information about trade transactions is stored in the cloud, and non-cash payments are made through a mobile POS-terminal. The cash register can replace traditional accounting systems in restaurants and shops (Ekkert, Nestorenko, Szynk, 2019).
A state-of-the-art direction of improving the management of banking services was the decision on the national level to create, at the initiative of PJSC "State Savings Bank of Ukraine”, OschadBankID platform, which is a means of identifying and verifying bank card users by government agencies, a digital signature for registration of permits, including for opening and conducting own business. This will improve the investment climate in the country and minimize the corruption component in the communication of citizens and businesses with government agencies.

In the conditions of financial shocks and instability of financial markets, the key to maintaining the bank's position in the market is, first of all, to reduce costs, to increase the speed of transactions and to minimize credit risks. Therefore, it is important for banks to find a new innovative model that would meet today's requirements. In this regard, a number of Ukrainian banks are working on the transition to the blockchain technology, based on which, it is possible to build the 
whole operation process of the bank, including the core of the bank (core banking system) and work with customers.

Blockchain is a decentralized database for recording and verifying transactions. In this case, network users are divided into two groups, namely: the regular users who create new records, and the miners who create blocks. Ordinary users create and distribute records over the network, for example, about money transfers or transfer of ownership.

Several Ukrainian banks are also planning to connect to Ripple technology. This technology is focused on financial institutions and is already actively used in three Western banks. It is both a payment system, a currency exchange and a network of money transfers. Its use will allow banks to transfer funds around the world instantly and almost free of charge. Innovations in payments can greatly simplify payment for goods and remittances. Moreover, modern technologies have a positive effect on the image of the bank and customers.

It should be noted that the national banking system has a strong innovation potential for active implementation of financial innovations, but the overall digitalization process needs to be accelerated (Ekkert, Nestorenko, Szynk, 2019).

\section{Innovative financial developments of the world's leading banks}

Radical innovations can displace the dominant business model or technology and create a new market. Analysis of innovative developments of banks around the world for the period 2015-2019 proves that financial innovations have changed their nature and are based on the latest digital technologies.

Las Vegas holds an annual BAI-Finance Global Banking Innovation Awards competition, in which the world's leading banks compete and demonstrate their innovative developments in various areas.

The most innovative financial services organizations for the period 2015-2019 were awarded The Bank of East Asia, Limited (Hong Kong, China), DenizBank (Turkey), Emirates NBD Bank (United Arab Emirates), USAA (San Antonio, TX, USA), City Ventures (USA) (Table 1) (The BAI Global Innovation Awards, 2021).

According to the BAI Global Innovation Awards, we can explore the rapid and successful development of innovative financial institutions.

The Bank of East Asia, Limited (BEA) has a long tradition of innovation. Dating as far back as 1969, BEA was one of the first Chinese banks in Hong Kong to introduce advanced technology to their operations with the installation of a state-of-the-art computer system. Always striving to provide bestin-class financial services, BEA upholds five core values: professionalism, customer-focus, integrity, progressiveness, and innovation. This ethos is the foundation stone, on which the culture of innovation within BEA is built, and over the years has enabled BEA to hold a strong track record as a market leader and pioneer in online banking. Through different channels, customers are invited to share opinions and suggestions, additionally; BEA is also dedicated to originality and in-house development.

To source the best ideas and encourage creative thinking, BEA welcomes suggestions from nearly 6,000 employees in Hong Kong. Ideas and suggestion can be submitted quarterly and a generous cash prize is awarded for the best entry. DenizBank's success in innovation lies in the composition of multiple factors. Special innovation teams and innovation committee structures are formed to focus on the customer's problems and innovative solutions together with the business and technology teams, which accelerate and encourage the innovation process. To improve its open innovation network, DenizBank continuously cooperates with intelligent business partners and works to develop new business models.

Emirates NBD is proud to be a global leader in innovation by developing smart and user-friendly products every year. With the mission of making its customers' lives simpler by providing solutions that help them fulfill their financial aspirations, innovation is a core value at Emirates NBD - driven from the Chairman, CEO and Executive Board to all levels of employees. Having already witnessed exceptional achievements, Emirates NBD promised to invest 500 million AED ( $\sim 140$ million USD) over the next three years in digital innovation. The bank's continued growth is a testimony to the exceptional dedication overall that makes ENBD a Factory of Innovation.

Innovation at USAA is purpose-driven. The purpose is their mission, facilitating the financial security of the military community, and delivering excellent service. Their focus starts with their members, how they can continue to serve them better than anyone else, and how they can maintain USAA's legacy for the next 100 years. Their innovations help make members' lives easier and enable them to be more financially secure. Through innovation, they seek to deliver tangible value to members, employees and USAA. Their 2017 innovations enabled 1.7 billion USD in value back to USAA and 5.3 million USD in cost savings were confirmed by their line of business partners. Over 92 percent of their employees participate in the innovation process.

Citi Ventures accelerates the adoption of the new business models and discovers new sources of value by exploring, incubating, and investing in new ideas in collaboration with Citi colleagues, our clients, and the innovation ecosystem.

Information about the winners and their innovative developments in the category "Product and Service Financial Innovation" according to the BAI Global 
Table 1

Most innovative financial services organization of the year

\begin{tabular}{|c|c|c|}
\hline Year & Innovator & Innovation \\
\hline 2015 & $\begin{array}{l}\text { The Bank of East Asia, } \\
\text { Limited } \\
\text { (Hong Kong, China) }\end{array}$ & $\begin{array}{l}\text { Taking a customer-centric approach, BEA continues to innovate to enhance the customer experience. } \\
\text { This is evident from the revitalization of SupremeGold which was a new direction for the bank and part } \\
\text { of BEA's ongoing commitment to constantly develop and search for advanced solutions to best suit their } \\
\text { customers' changing needs. }\end{array}$ \\
\hline 2016 & $\begin{array}{l}\text { DenizBank } \\
\text { (Turkey) }\end{array}$ & $\begin{array}{l}\text { Besides organizational positioning, DenizBank is committed to diffusing an innovative culture } \\
\text { throughout the company where every employee believes in collective wisdom and synergy. As } \\
\text { customers are more connected than ever, all DenizBankers devote themselves to innovative thinking and } \\
\text { creative values. In addition, DenizBank adopted an eco-system banking approach and puts significant } \\
\text { effort towards building a digital ecosystem with all crucial players. }\end{array}$ \\
\hline 2017 & $\begin{array}{l}\text { Emirates NBD Bank } \\
\text { (United Arab Emirates) }\end{array}$ & $\begin{array}{l}\text { The bank continuously aims to infuse the innovative culture with periodic training programs, special } \\
\text { events, internal 'EDGE' innovation programs, external innovation with open banking initiatives and } \\
\text { FinTech hangouts within the bank. The futuristic way of banking, namely the 'Future Lab', is the center } \\
\text { of innovation management where the jury 'Innovation Champions' evaluate ideas and map innovative } \\
\text { solutions. }\end{array}$ \\
\hline 2018 & $\begin{array}{l}\text { USAA } \\
\text { (San Antonio, TX, } \\
\text { USA) }\end{array}$ & $\begin{array}{l}\text { At USAA, everyone is an innovator! Our mission and culture provide our purpose, and our employees } \\
\text { bring their passion to serve our members better than anyone else. The goal of employee innovation is } \\
\text { to empower all employees to creatively innovate to best serve members and to prepare USAA for the } \\
\text { future. We use a toolkit of various innovation programs (challenge-based innovation, hackathons, coding } \\
\text { competitions, education/training) to engage employees to help solve strategic challenges. }\end{array}$ \\
\hline 2019 & $\begin{array}{l}\text { City Ventures } \\
\text { (USA) }\end{array}$ & $\begin{array}{l}\text { Citi Ventures accelerates the adoption of the new business models and discovers new sources of value by } \\
\text { exploring, incubating, and investing in new ideas in collaboration with Citi colleagues, our clients, and } \\
\text { the innovation ecosystem. }\end{array}$ \\
\hline
\end{tabular}

Source: systematized by the authors on the basis of (The BAI Global Innovation Awards, 2021)

Table 2

Product and service financial innovation

\begin{tabular}{|c|l|l|}
\hline Year & \multicolumn{1}{|c|}{ Innovator } & \multicolumn{1}{c|}{ Innovation } \\
\hline $\mathbf{2 0 1 5}$ & $\begin{array}{l}\text { Fidor Bank AG } \\
\text { (Germany) }\end{array}$ & $\begin{array}{l}\text { A free bank account built around an Application Programming Interface (API), the Fidor Smart Current } \\
\text { Account supplements classic account services with Internet payments and innovative banking products. } \\
\text { The integrated API platform allows customers and partners to directly connect their computer systems } \\
\text { with those of Fidor Bank. }\end{array}$ \\
\hline $\mathbf{2 0 1 7}$ & $\begin{array}{l}\text { CEO Mobile } \text { biometrics is Wells Fargo's latest security innovation. CEO Mobile biometrics sets a new } \\
\text { standard for mobile banking security and makes banking easier by giving customers a fast, secure way to } \\
\text { access their mobile banking services without using passwords or tokens. }\end{array}$ \\
\hline $\mathbf{2 0 1 8}$ & $\begin{array}{l}\text { Pay-per-mile car insurance. Metromile is revolutionizing car insurance through the use of technology } \\
\text { with its pay-per-mile insurance model. By offering affordable car insurance, transparent pricing based on } \\
\text { the miles customers actually drive, data to optimize how customers use their car, and instant access to } \\
\text { detailed vehicle diagnostics via the driving app. }\end{array}$ \\
$\begin{array}{l}\text { NovoPayment, Inc. } \\
\text { Miami, USA) }\end{array}$ & $\begin{array}{l}\text { Embedding FinServ in Gig Value Chain. NovoPayment's innovation leverages emerging technologies } \\
\text { to seamlessly deliver in-context services to the client, and an excellent experience to their end customer. } \\
\text { NovoPayment's API-powered technology allows Banco Pichincha Colombia to dynamically deliver } \\
\text { financial services and frictionless user experiences to their gig economy clients, without the need to alter } \\
\text { their core systems or sacrifice security and compliance. This innovation allows the client's platform-driven } \\
\text { business to pull important instant issuance and mass payout services on demand and with the scalability } \\
\text { they require. }\end{array}$ \\
\hline $\begin{array}{l}\text { Fechnology Co., Ltd } \\
\text { (China) }\end{array}$ & $\begin{array}{l}\text { FiMAX Trade Finance Blockchain Network is a blockchain solution that aims to organically connect } \\
\text { different parties in trade finance. On this reliable, secure and efficient network, different parties in trade } \\
\text { can directly finance and exchange data while preserving full data privacy, all of which is enabled by } \\
\text { blockchain architecture and cryptography solutions. }\end{array}$ \\
\hline
\end{tabular}

Source: systematized by the authors on the basis of (The BAI Global Innovation Awards, 2021) 
Innovation Awards are systematized and presented in Table 2.

Consider their innovative achievements in more detail. The open financial ecosystem Fidor Smart Current Account provides app partners the ability to continuously increase the range of products and service that enable customers to select products and services they want from either Fidor Bank or third-party providers. The steadily growing range of products guarantees a modern banking experience that helps deepen existing customer relationships and attract new customers. The features include credit transfers via Twitter, social lending, social trading in virtual currencies and a wide range of cutting-edge products that go well beyond traditional banking services.

The CEO Mobile service is unique in that, it offers customers a choice in how to sign on. Customers can sign on using the CEO Mobile Eyeprint feature, or their ID and password. The CEO Mobile Eyeprint feature uses a customer's mobile device to create a template of their eye veins that can be used to identify them when they sign on, which saves time and eliminates the need to remember passwords and carry tokens.

Metromile is revolutionizing car insurance through the use of technology with its pay-per-mile insurance model. Metromile is transforming car insurance - and car ownership - to be more intelligent, seamless and accessible than ever before.

NovoPayment's API-powered technology allows Banco Pichincha Colombia to dynamically deliver financial services and frictionless user experiences to their gig economy clients, without the need to alter their core systems or sacrifice security and compliance. The innovation solves two broader problems and several specific pain points. The first problem is banks and FI's general difficulty in serving modern, platform-driven businesses, such as gig economy companies, which often feature real-time IT platforms and exponential scaling operations. The second problem has to do with the undesirable impacts that cash-intensive processes have on these businesses and their ability to scale (compete for capital, workers, and market share) and operate in the fully digital fashion on which the best in their field are modeled. This problem is exacerbated in cash-intensive markets such as Latin America where large shares of the population lack formal banking relationships and electronic payment instruments.

FiMAX Trade Finance Blockchain Network is a blockchain solution, by onboarding data from different participants, the network forms a healthy, closed-loop data flow within the ecosystem. Enterprises can more easily prove the validity of their trades and better apply for financing. Banks can conduct more accurate credit assessments, lowering financial risk.

The winners in the nomination "Channel Financial Innovation" in 2015-2019 were The Bank of East Asia, Limited (Hong Kong, China), Mizuho Financial Group, Inc., HDFC Bank Limited, Ping An Technology (Shanghai, China), Royal Bank of Canada (Table 3).

Table 3

Channel financial innovation

\begin{tabular}{|c|c|c|}
\hline Year & Innovator & Innovation \\
\hline 2015 & $\begin{array}{l}\text { The Bank of East Asia, } \\
\text { Limited } \\
\text { (Hong Kong, China) }\end{array}$ & $\begin{array}{l}\text { Digital Branch: A New Way to Bank. The Bank of East Asia, Limited (BEA) launched a highly } \\
\text { flexible and mobile digital branch that operates as a paperless, straight-through model. The digital } \\
\text { branch has a footprint of just half the floor space of a traditional branch, and takes only } 13 \text { days } \\
\text { to renovate and install. The branch contains a much smaller back-office area and requires reduced } \\
\text { manpower, enabling BEA to open in high-footfall luxury shopping malls. }\end{array}$ \\
\hline 2016 & $\begin{array}{l}\text { Mizuho Financial } \\
\text { Group, Inc. }\end{array}$ & $\begin{array}{l}\text { Mizuho Financial Group, Inc. has launched an innovative branch solution with the deployment of } \\
\text { "Pepper" the emotional humanoid robots that act as a concierge, in the traditional formal Japanese } \\
\text { bank branches. The primary impacts anticipated from this original innovation are to improve service } \\
\text { to customers using AI and Big Data, and to provide a unique UX through Digital Omotenashi*. }\end{array}$ \\
\hline 2017 & HDFC Bank Limited & $\begin{array}{l}\text { HDFC Bank On Chat is a chat-based platform on Facebook messenger which provides commerce } \\
\text { services like bill payments, travel bookings, event bookings, etc. Since HDFC Bank OnChat is } \\
\text { built on an intuitive Natural Language Processing (NLP) based Artificial Intelligence platform, it } \\
\text { understands its user's intent based on free text input. A user just needs to chat with HDFC Bank } \\
\text { OnChat on Facebook messenger to complete any transaction. }\end{array}$ \\
\hline 2018 & $\begin{array}{l}\text { Ping An Technology } \\
\text { (Shanghai, China) }\end{array}$ & $\begin{array}{l}\text { Emotion Recognition Based Financial Risk Management System. Combining psychology } \\
\text { and AI to assist credit analysts in credit review. Solution utilizes the results of psychological study, } \\
\text { adopts AI methods, and extracts the abnormal performance of people when they tell lies to provide } \\
\text { assistant judgment for the credit review process. It lowers the professional threshold of credit analysts, } \\
\text { improves the efficiency of credit review, reduces the bad debt ratio. }\end{array}$ \\
\hline 2019 & $\begin{array}{l}\text { Royal Bank of Canada } \\
\text { (Canada) }\end{array}$ & $\begin{array}{l}\text { DRIVE, a mobile and web app, keeps Canadian car owners on top of maintenance and essential } \\
\text { car services - from booking service appointments, to staying up to date on safety recalls, to storing } \\
\text { essential ownership details and documents, and more. }\end{array}$ \\
\hline
\end{tabular}

Source: systematized by the authors on the basis of (The BAI Global Innovation Awards, 2021) 
Another relevant and important nomination is "Human Capital Innovation". The finalists of the BAI Global Innovation Awards were:

- Citizens Financial Group Jamie Virtual Career Assistant (United States) enables an impactful, personalized, and modern candidate experience to all prospects and delivers efficiencies and new capabilities throughout the recruitment process. Jamie uses intuitive, conversational language, and can understand the natural language of the user. She even uses emoji's in her responses! External job seekers have leveraged their chat with Jamie to search for open jobs and kick-off the application process. Jamie has interacted with more than 18,000 candidates answering 60,000 inquiries on benefits, company culture and interview process, plus topical questions on Citizens' approach to COVID-19 and Diversity, Equity and Inclusion.

- Sberbank, Employee Digital Care Program (Russia), the Employee Digital Care Program of Sberbank identifies and seeks to prevent undue stress for employees at all stages of their career path within the bank. By using a host of digital tools and technologies, gamification, as well as offering psychological support, this programme has positively impacted the level of employee engagement and satisfaction as well as employee efficiency. It has also resulted in improved customer satisfaction scores.

- Ziraat Bank, Hidden Power of Communication (Turkey), with the help of analytics, Ziraat Bank identified various factors of the increased employee dissatisfaction and bottlenecks in communication. Based on the data, they created an innovation designed to strengthen the communication network among employees and to recognize and take precautions in case of any communication problem. The main purpose of the innovation is to establish connections in workplace, to build a culture that aligns with people's demand and to increase the level of the workplace communication.

Among the winners in 2015-2019 in the nomination "Financial Innovation in Social and Community Impact", the following nominees were determined: Nusenda Credit Union (United States), TEB Women Banking (Turkey), Taqanu, RUKULA (PVT) LIMITED (Colombo, Sri Lanka), USAA (San Antonio, TX, USA), JUMO (South Aftrica).

The main innovative ideas of the award winners are systematized and presented in Table 4.

The next nomination worth paying attention to is "Financial Innovation in Internal Process Improvement". The innovative banks in this direction in

Table 4

Financial innovation in societal and community impact

\begin{tabular}{|c|c|c|}
\hline Year & Innovator & Innovation \\
\hline 2015 & $\begin{array}{l}\text { Nusenda Credit Union } \\
\text { (United States) }\end{array}$ & $\begin{array}{l}\text { Co-op Capital: Widening Access Points to Financial Products. Nusenda Credit Union created } \\
\text { Co-op Capital, a collaborative financial product that combines micro-lending and community } \\
\text { sponsors. This is the only product on the market that allows the target population to access capital } \\
\text { through a trusted community organization versus a financial institution. Uniquely, member } \\
\text { organizations (co-ops, networks, unions, etc.) sponsor the loan application for their affiliates and } \\
\text { provide the loan underwriting, while Nusenda Credit Union does the originating. }\end{array}$ \\
\hline 2016 & $\begin{array}{l}\text { TEB Women Banking } \\
\text { (Turkey) }\end{array}$ & $\begin{array}{l}\text { Turk Ekonomi Bankasi (TEB)'s establishment of a separate department to provide Women's Banking } \\
\text { services that provide solutions to the obstacles women face in business. TEB is the first and only bank } \\
\text { in Turkey which has set up a separate department and has begun providing Women's Banking services. }\end{array}$ \\
\hline 2017 & Taqanu & $\begin{array}{l}\text { Taqanu opens the financial ecosystem for anyone by using a blockchain-based digital ID to enable } \\
\text { financial inclusion and create equal opportunities. } \\
\text { The core goal is to enable anyone with a smartphone access to a simple banking solution without the } \\
\text { burden of a local regulatory regime, while also managing Anti-Money Laundering (AML) risks. }\end{array}$ \\
\hline \multirow[t]{2}{*}{2018} & $\begin{array}{l}\text { RUKULA (PVT) } \\
\text { LIMITED } \\
\text { (Colombo, Sri Lanka) }\end{array}$ & $\begin{array}{l}\text { Credit for small consumer durables for the financially excluded in Sri Lanka. Using Sri Lanka's } \\
\text { first non-financial attribute based alogorithm, Rukula seeks to help the most financially vulnerable } \\
\text { citizens of Sri Lanka obtain small consumer goods. Although customers are encouraged to keep up } \\
\text { with their payments, we acknowledged that these communities would have significant and multiple } \\
\text { financial hardships during the course of their credit period. Consequently, there are no interest costs or } \\
\text { penalties for late payments. }\end{array}$ \\
\hline & $\begin{array}{l}\text { USAA } \\
\text { (San Antonio, TX, } \\
\text { USA) }\end{array}$ & $\begin{array}{l}\text { Aerial Imagery Tool. The aerial imagery tool utilizes before and after images to assess damage so } \\
\text { anyone can type in an address and see the images of the address before the hurricane and after. } \\
\text { This allows members the ability to remotely search and view damage to their homes, regardless of if } \\
\text { they were able to return to their homes to assess damage. }\end{array}$ \\
\hline 2019 & $\begin{array}{l}\text { JUMO } \\
\text { (South Africa) }\end{array}$ & $\begin{array}{l}\text { JUMO Platform. JUMO offers traditionally hard-to-reach customers a range of instant, affordable, } \\
\text { high-quality borrowing choices via mobile phoneJUMO uses individual data to structure and fit } \\
\text { products to suit the customer's needs. Sophisticated data prediction and credit scoring methods allow } \\
\text { JUMO to leapfrog prohibitive operational and risk costs. }\end{array}$ \\
\hline
\end{tabular}

Source: systematized by the authors on the basis of (The BAI Global Innovation Awards, 2021) 
2015-2019 were: DenizBank (Turkey), Alior Bank S.A., Live Oak Bank (Wilmington, NC, USA) and Citi Ventures (USA) (Table 5).

According to the results of the finals of the BAI Global Innovation Awards, the finalists in the nomination "Financial Innovation in Internal Process Improvement", 5 banks were identified with the following innovative developments:

- CaixaBank S.A. (Spain) - this innovation seeks to offer customers agile mobility through different products available at CaixaBankNow. The Mobility project mainly has an impact on the environment and on the contracting of products through $100 \%$ digital channels, which are very necessary at this time.

- Deniz Bank (Turkey) - the Digital Scorecard is a broad monitoring system used to evaluate employees' performance at promoting the use of digital channels to customers. Digital Scorecard is helping the employees to analyse their customers' daily-weeklymonthly transactions and helping them to direct customers to the right digital channel vs. having them use physical branches. This only helps customers reduce time and money spent, but also helps the branches improve profitability due to increased use of low cost digital channel.

- ICICI Bank (India), OPTIMUS - Payment Invoicing and ID Card Issuance System is an online web-based platform for online invoicing for payment disbursement, eSigned invoices submission, NDC submission, ID Card issuance request, two-way digital communication for our outsourced agencies, online profile updating, submission of KYC documents and a declaration collection medium from vendors. Online ID Card issuance is an Industry First and is Go Green Initiative.

- OneConnect Smart Technology Co., Ltd. (Shen Zhen Bank) (China) - The Smart Contract Cloud platform builds a real-time risk prediction model based on the contract risk concern tag, which forecasts the probability of contract clause default and defines the clause risk level. Simultaneously, it interfaces with external data sources, constructs a portrait of the contract subject, establishes mapping rules, generates risk alerts, and provides risk warning.

- SberBank (Russia), Contact Center Internal Improvement Process - An intelligent quality management system that helps to provide the highest quality of service to customers. This system was built using advanced technologies and proprietary AI-based modules, which help the bank to gather insights and to make decisions. Processing and storage of all data takes place in the bank's internal circuit, ensuring a high level of security.

\section{Conclusions}

In today's rapidly evolving digitalization processes, financial innovations play an extremely important role and contribute to the economic development of

Table 5

Financial innovation in internal process improvement

\begin{tabular}{|c|c|c|}
\hline Year & Innovator & Innovation \\
\hline 2015 & $\begin{array}{l}\text { DenizBank } \\
\text { (Turkey) }\end{array}$ & $\begin{array}{l}\text { Powerful Teller-Dashboard: Enhancing Customer Experience at Every Contact Point. DenizBank } \\
\text { developed Powerful Teller-Dashboard to place greater emphasis and importance on the customer experience } \\
\text { at every contact point. The platform aligns the customer relationship management (CRM) strategies, } \\
\text { predictive analytics and data mining analytics with a user friendly intelligent interface. }\end{array}$ \\
\hline 2016 & Alior Bank S.A. & $\begin{array}{l}\text { Smart Collect - Intelligent Automated and Scenario-based Process of Debt Collection. With Smart } \\
\text { Collect, Alior Bank introduced a sophisticated strategy of debt collection that is supported by data analysis } \\
\text { tools, automated generation and management of client-based campaigns; and employing multiple contact } \\
\text { channels tailored to each customer, including AI agents used for contact-center campaigns. }\end{array}$ \\
\hline 2017 & $\begin{array}{l}\text { DenizBank } \\
\text { (Turkey) }\end{array}$ & $\begin{array}{l}\text { Intelligent Workforce Management. Instead of the siloed centralization of operations, Intelligent } \\
\text { Workforce Management effectively prioritizes based on CRM techniques. It makes calculations based on } \\
\text { comprehensive mathematical models, creates automated and competency-based task assignments, and } \\
\text { forecasts workload balances based on a variety of data sources. }\end{array}$ \\
\hline 2018 & $\begin{array}{l}\text { Live Oak Bank } \\
\text { (Wilmington, NC, } \\
\text { USA) }\end{array}$ & $\begin{array}{l}\text { Cloud Service Operations for Boundary-less Anytime-Anywhere Employee Enablement. Over } \\
\text { the course of } 18 \text { months, Live Oak Bank completely transitioned its internal IT infrastructure and all } \\
\text { applications to a pure Microsoft Azure cloud environment, empowering all employees to serve customers } \\
\text { anytime, anywhere, with highly secure yet intuitively accessible cloud applications. Employees can sign } \\
\text { up new customers and service existing ones anywhere, anytime using only laptops, smartphones and the } \\
\text { power of the cloud to originate and process loans, process deposits and provide other banking products and } \\
\text { services. }\end{array}$ \\
\hline 2019 & $\begin{array}{l}\text { Citi Ventures } \\
\text { (USA) }\end{array}$ & $\begin{array}{l}\text { ProxymitySM is a new digital proxy voting platform for corporate shareholders. The platform directly } \\
\text { connects and authenticates equity issuers and investors and makes the voting process more efficient, } \\
\text { accurate and transparent. Proxymity provides real-time transparency into the voting process, allowing instant } \\
\text { amendment of instructions and much sought-after confirmation that votes have been recorded at the annual } \\
\text { general meeting. }\end{array}$ \\
\hline
\end{tabular}

Source: systematized by the authors on the basis of (The BAI Global Innovation Awards, 2021) 
countries. Banking institutions need to concentrate their potential as much as possible on identifying priority digital and innovative initiatives, taking into account current challenges and threats. After all, the effective use of specific financial innovations requires extensive knowledge of the peculiarities of their operation and careful analysis of their consequences. An important element in the process of implementing financial innovations is the use of a cross-functional approach, which allows for flexibility and the ability to transform changes over time.

Given the experience of the leading banking institutions that actively implement innovative developments, it should be noted that along with the benefits, financial innovations can bring new challenges and threats to all participants in this process. The authors prove that radical innovations can displace the dominant business model or technology and create a new market.

The innovative developments of banks around the world for the period 2015-2019 are analysed within the article. Particularly according to The BAI Global Innovation Awards the leading position in the ranking "Most Innovative Financial Services Organization" in 2019 was occupied by City Ventures (USA) that accelerates the adoption of the new business models and discovers new sources of value by exploring, incubating, and investing in new ideas in collaboration with the innovation ecosystem. In 2019 the Chinese OneConnect Financial Technology Co., Ltd has implemented the FiMAX Trade Finance Blockchain Network - a blockchain solution that aims to organically connect different parties in trade finance (the blockchain architecture and cryptography solutions within this network allows to all parties to finance and exchange data safely and reliable while preserving full data privacy). Modern financial innovation have societal and community impact, for instance, in 2019 JUMO (South Africa) offered a range of instant, affordable, high-quality borrowing choices via mobile phone to the group of customers who are traditionally determined as hard-to-reach (wherein the prohibitive operational and risk costs are leapfrogged by the JUMO through implementation of sophisticated methods of data prediction and credit scoring). The most widespread application of financial innovations is traditionally in the Internal Process Improvement. As an example it could be noted the Citi Ventures (USA) that developed the ProxymitySM - the digital proxy voting platform for corporate shareholders (advantages of this innovation: directly connection and authentication of equity issuers and investors; more transparent, efficient, accurate, real-time voting process; etc.). The conducted analyses showed that financial innovations have changed their nature and are based on the latest digital technologies.

Acknowledgments. This research is carried out within the framework of the scientific project "Transformation of households' behaviour in the financial services market in the context of digitalization" with the support of the Ministry of Education and Science of Ukraine.

\section{References:}

Al-Kaber, M. (2010). Rynki finansowe, Białystok: Wydawnictwo Wyższej Szkoły Ekonomicznej w Białymstoku.

Anderloni, L., \& Bongini, P. (2009). Is Financial Innovation Still a Relevant Issue? In L. Anderloni, D. T. Llewellyn, R. H. Schmidt (ed.), Financial Innovation in Retail and Corporate Banking, Cheltenham: Edward Elgar.

Błach, Joanna (2011). Financial innovations and their role in the modern financial system-identification and systematization of the problem. e-Finanse: Financial Internet Quarterly, 7(3), 13-26.

Butko, M., Popelo, O., \& Pishenin, I. (2019). Innovations in Human Resources Management in the Eurointegration Conditions: Case for the Ukrainian Agro-Industrial Complex. Marketing and management of innovations, (2), 74-82. Butko, M., Ivanova, N., Popelo, O., \& Samiilenko, G. (2020). Conceptual foundations of the regional industrial cluster formation based on the European experience and leading world tendencies. Financial and credit activity: Problems of theory and practice, 1(32),319-329.

Chien-Chiang, Lee, Chih-Wei, Wang, \& Shan-Ju Ho (2020). Financial innovation and bank growth: The role of institutional environments. The North American Journal of Economics and Finance, 53, 101195.

Chrystalla, Kapetaniou, Marios Samdanis, Soo Hee Lee. (2018). Innovation policies of Cyprus during the global economic crisis: Aligning financial institutions with National Innovation System. Technological Forecasting and Social Change, 133, 29-40.

David W. Perkins (2020). Fintech: Overview of Innovative Financial Technology and Selected Policy Issues. Congressional Research Service, R46332.

Domingo García-Pérez-de-Lema, Daniel Ruiz-Palomo, Julio Diéguez-Soto (2021). Analysing the roles of CEO’s financial literacy and financial constraints on Spanish SMEs technological innovation. Technology in Society, 64, 101519.

Ebubekir Mollaahmetoğlu, Burçay Yaşar Akçalı (2019). The Missing-Link between Financial Development and Economic Growth: Financial Innovation. Procedia Computer Science, 158, 696-704.

Ekkert, M., Nestorenko, O., \& Szynk, M. (Eds.) (2019). Modern innovative and information technologies in the development of society. Wydawnictwo Wyższej Szkoły Technicznej w Katowicach. 
Fabozzi, F. J., \& Modigliani, F. (2003). Capital Markets. Institutions and Instruments. Upper Saddle River: Pearson Education International.

Fedyshyn, M. F., Abramova, A. S., Zhavoronok, V., \& Marych, M. G. (2019). Management of competitiveness of the banking services. Financial and credit activity: problems of theory and practice, 1(28), 64-74. doi: 10.18371/ fcaptp.v1i28.163340

Frame, W. S., \& White, L. J. (2009). Technological Change, Financial Innovation, and Diffusion in Banking (Working Paper 2009-10). Atlanta: Federal Reserve Bank of Atlanta.

Gang-Jin Wang, Yang-Yang Chen, Hui-Bin Si, Chi Xie, \& Julien Chevallier (2021). Multilayer information spillover networks analysis of China's financial institutions based on variance decompositions. International Review of Economics \& Finance, 73, 325-347.

Hui An, Ruibo Yang, Xuejiao Ma, Siqi Zhang, \& Sardar M. N. Islam (2021). An evolutionary game theory model for the inter-relationships between financial regulation and financial innovation. The North American Journal of Economics and Finance, 55, 101341.

Juliana Albuquerquer Saliba de Oliveira, Leonardo Fernando Cruz Basso, Herbert Kimura, \& Vinicius Amorim Sobreiro (2018). Innovation and financial performance of companies doing business in Brazil. International Journal of Innovation Studies, 2(4), 153-164.

Katrin, Hahn (2019). Innovation in times of financialization: Do future-oriented innovation strategies suffer? Examples from German industry. Research Policy, 48(4), 923-935.

Kholiavko, N. (2017). Systematization of Scientific Approaches to the Interpretation of Information Economy. Baltic Journal of Economic Studies, 3(4), 157-164.

Kosach, I. A., Zhavoronok, A. V., Fedyshyn, M. F., \& Abramova, A. S. (2019). The role of commission receipts in the formation of the commercial bank revenue. Financial and credit activity: problems of theory and practice, 4(31), 22-30. doi: 10.18371/fcaptp.v4i31.190781

Loiko, V., \& Bashkyrtseva, T. (2018). Innovations as a power of banking activity. European Scientific Journal of Economic and Financial Innovation, (1), 67-76.

Meifang Yao, He Di, Xianrong Zheng, \& Xiaobo Xu (2018). Impact of payment technology innovations on the traditional financial industry: A focus on China. Technological Forecasting and Social Change, 135.

PK Senyo, \& Ellis L. C. Osabutey (2020). Unearthing antecedents to financial inclusion through FinTech innovations. Technovation, 98, 102155.

Saksonova, S., \& Kuzmina-Merlino, I. (2017). Fintech as Financial Innovation - Possibilities and Problems of Implementation. European Research Studies Journal, XX(3A), 961-973.

Shkarlet, S., Dubyna, M., \& Zhuk, O. (2018). Determinants of the financial services market functioning in the era of the informational economy development. Baltic Journal of Economic Studies, 4(3), 349-357.

Shkarlet, S., Ivanova, N., Popelo, O., Dubyna, M., \& Zhuk, O. (2020). Infrastructural and Regional Development: Theoretical Aspects and Practical Issues. Studies of Applied Economic, 38-3(1).

Shkarlet, S., Kholiavko, N., \& Dubyna, M. (2019). Information Economy: Management of Educational, Innovation, and Research Determinants. Marketing and Management of Innovations, 3, 126-141.

The BAI Global Innovation Awards (n.d.). Retrieved (10.03.2021) from https://www.bai.org/globalinnovations

Vovk, V. Y., Zhezherun, Yu. V., \& Kostohryz, V. G. (2019). Bank lending to small and medium-sized enterprises: the experience of Ukraine and Poland. The bulletin of the national academy of sciences of the Republic of Kazakhstan, 2(378), 70-78. doi: 10.32014/2019.2518-1467.42.

Vovk, V. Y., Zhezherun, Yu. V., Kostohryz, V. G., \& Maliarova, V. O. (2021). Development of the Banking Sector of Ukraine in the Space of Formation of Destructive Consequences of the Influence of the Global Financial and Economic Crises: Economic and Legal Aspects. Bulletin of the National Academy of Sciences of the Republic of Kazakhstan, 1(389), 137-145. doi: 10.32014/2021.2518-1467.19

Xin Long Xu, Tao Shen, Xi Zhang, \& Hsing Hung Chen (2020). The role of innovation investment and executive incentive on financial sustainability in tech-capital-labor intensive energy company: Moderate effect. Energy Reports, 6, 2667-2675. 